\title{
The perfection and innovation of institutional pension service from the perspective of social work
}

\author{
Zhao Junrong \\ Yunnan University of Finance and Economics \\ zjrong7343@163.com
}

\begin{abstract}
China, there are many lags and deficiencies in the institutional pension service, and the service mode and service content need to be improved and innovated. By analyzing the present situation, deficiency and reasons of institutional pension service in China, this paper combines with the advantages of social work profession in institutional pensionservice, and puts forward some countermeasures and suggestions to perfect institutional pensionservice.
\end{abstract}

Keywords-institutional pension; social work; service perfection

\section{OVERVIEW OF THE BACKGROUND}

\section{A.Current situation of ageing of population in China}

With the rapid development of economy and society and the improvement of medical and health conditions, the standard of living of residents has been improved significantly, and at the same time, the life expectancy of the population has also been prolonged, which has contributed to the fact that China's population is becoming more and more aging and old aging. According to the China Statistical Yearbook in 2016, China's total population reached 1.3746 billion in 2015, with 143.9 million people aged 65 and over, which was $10.5 \%$ of the total population. The changing trend of population aging and the future pension problem for the large elderly population have become an unavoidable social issue.
The aging issue in China is facing three major challenges. One is the rapid aging. The second is the aging of the elderly. The third is family empty nesting.

\section{B. Concept definition of institutional pension and historical} inevitability

Institutional pension is a pension model that based on social institutions as pension area, relying on state support, family support or elderly self-help, but by the pension institutions to provide pensioncare function, including nursing home, apartment for the aged, care home for the elderly.

The large amount of population flow leads to the miniaturization and kernelization of family structure in our country, and the function of family pension is weakening gradually. It is becoming more and more difficult to provide life care and spiritual comfort for the elderly at home. The family pension function is gradually separated into the specialized social sector, and the socialized pension institution is the substitute to adapt to this change.

\section{CURRENT SITUATION AND DEMANDS ASSESSMENT} OF PENSION INSTITUTIONS

\section{A.Current situation}

As a supplement to the family pension, institutional pension is the most traditional social pension model, it is still the choice of most elderly people, especially for the sick elderly and empty nest elderly. The demand for 
institutional pension continues to grow. Among existing pension service organizations, there are mainly the following problems:

1)The construction of pension institutions is seriously lagging behind. Most of the existing pension institutions have problems such as small scale of construction, few beds, low standards, shortage of equipment, difficult operation of funds. The pension service mostly stays in the basic life care, the service function is not complete and lacks the specialized talented person.

2)There are no clear regulations on service standard, facility standard, charge standard, legal relationship, so the pension institutions are uneven.

3)The operating costs of the pension institutions are higher, besides the tax relief, there's no institutionalized preferential treatment in water, electricity, land use, construction and other aspects.

4)Pension institutions are low-profit industries point. In order to increase the occupancy rate, private pension institutions are playing the price war to keep the price down, resulting in a decrease in service quality.

Therefore, only by further improving and innovating the service of institutional pension, the social resources can be fully utilized. Only by making use of the value of pension institutions can the pension institutions truly shoulder the responsibility of social pension.

\section{B.Demands assessment and cause analysis}

The common demands of pension institutions are mainly reflected in the following aspects:

1)Lack of quality nursing staff

There are mainly two kinds of background of nursing workers in pension institutions, one is local people, most of them have been laid off and retired; the other is migrant workers. The majority ofthem are women and low education level. In an ordinary public nursing home, the average nursing worker is responsible for three elderly people with insufficient self-care all-roundly.

The funds of public nursing homes are limited, the wages and benefits of nursing workers are not high, institutions are lack of further skill training for nursing workers, the loss of personnel is serious, nursing workers in short supply. At the same time, the nursing staffs have a high degree of mental and physical exertion and a low sense of value, which makes the nursing work is difficult to further meticulous.

2)Single services content and lack of spiritual care for the elderly

It is found that most institutions do not have special social work service departments or social workers, and the services provided by pension institutions are mainly based on living care, cleaning and medical treatment of the elderly. The cultural life, psychological care, social support for the elderly are relatively lacking. The care demands of the elderly at the spiritual level have not been given adequate attention. The inner demands of the elderly are often overlooked. For some organizations, even if they have a good concept of service, it is difficult for them to seek professionals who can do psychological care because of the restrictions of objective conditions.

3)Contradictions between institutions, the elderly and family members need to be reconciled

Because of the different needs and different position, contradictions and disputes always exist among the institutions, the elderly and their families. These contradictions and disputes involve various aspects such as money, services, life details, etc. It is difficult to avoid and needs to be solved effectively.

4)To enhance continuity of docking services

With limited resources and insufficient social support, pension institutions often become "showrooms" for volunteer services on holidays. Voluntary activities are difficult to deepen and continue. A large number of pension institutions need to establish long-term and continuous cooperative relationship with volunteers from outside.

\section{ADVANTAGES OF SOCIAL WORK SERVICES}

\section{IN INSTITUTIONAL PENSION}

Social work intervention in institutional pension means applying the theories, methods and techniques of social work to institutions to assist the elderly in solving such problems as 
physiology, life, medical treatment, mentality and religious beliefs, improve the physical and mental health care and social adaptation of the elderly so that they can spend their twilight years with dignity, happiness and value. The pension institution is an ecosystem composed of the elderly system, the elderly family system, the community system and so on. In the service process, social workers can take a multi-system intervention model, coordinate the operation of each system, fully mobilize the resources of each system to maintain the balance of the entire ecosystem.

\section{A.Service advantages}

Social workers have a sociological, psychological background and professional counselling skills. They can enrich the life of the elderly in organizations through individual counselling, group counselling, recreational activities and so on. They motivate the elderly to help each other, so as to encourage the elderly to enhance their sense of self-worth in various activities. Social workers can also provide hospice care services for the elderly who are seriously ill and old.

In addition to caring for the elderly, social workers can also help the nursing workers to enhance their professional knowledge and skills through a series of activities. Relief of care workers' pressure can improve the quality of care services.

\section{B.Management advantages}

Social workers are not only service providers, but also managers. Social workers can effectively coordinate the relationship among the elderly, hospital and family, build a communication platformamong the three parties, which is conducive to coordinate and resolute of the contradictions among the three parties objectively and impartially.

\section{C.Resource advantages}

Social workers are the integrators of social resources, which can build a social support network to meet the spiritual needs of the elderly, strengthen the ties between pension institutions and families, enterprises, schools and other industries to improve the mental health of the elderly, meet the individual needs of the elderly, reduce the sense of social isolation formed by the elderly living in pension institutions for a long time, and help the elderly to integrate into the society.

\section{COUNTERMEASURES AND SUGGESTIONS FOR} PERFECTING INSTITUTIONAL PENSION SERVICE

\section{A.Promotion of government purchases of social services}

At present, most of the pension institutions in China belong to the public, because of the lack of market competitiveness, the institutions are falling behind and lacking innovation. The government should gradually introduce social resources to stimulate market vitality. The government, market and society can jointly build the pension service. In this process, the government acts as the link, coordinator and supervisor of resources to promote the efficient and high quality operation of pension service institutions.

\section{B.Introduction of social work services}

Most of the pension service organizations in China are mainly based on life and medical care and supplemented by cultural and spiritual life. This type of pension service has been unable to meet the needs of social development, nor can it satisfy the wishes of the elderly to live happily in their old age. The development of social work in China is becoming more and more mature. Social workers play more and more professional values in pension services. The advantages of social work pension services are obvious. It is an irresistible trend to introduce social work services into pension institutions.

\section{C.Introducing university resources and developing a rich} and sustainable voluntary service

At present, more than 200 colleges and universities in the mainland of China have set up the major of social work. Social work for the elderly is an important practical field. The internship andpractice of a large number of students can promote the establishment of long-term cooperative relationship between institutions and universities, and make up for the shortcomings of the current pension institutions, such as insufficient personnel, low service quality and so on. Professional internship mechanism can not only guarantee the quantity and quality of service, but also guarantee the 
continuity of service, and it can bring potential employees and volunteers for pension institutions.

\section{REFERENCES}

[1] Feng Xiaojuan. Analysis on the development state of pension service and social work intervention in China $[\mathrm{J}]$. Theory and Modernization, 2013,(1): 72-75.(In Chinese)

[2] Li Jinfang. Mechanism innovation of community pension service in the context of aging[J].Science and Technology Entrepreneurship,2017,(6):119-122. (In Chinese)
[3] Luan Wenjing, Li Xiang. Role analysis of social work intervention in institutional pension services[J]. Social Work, 2014, (5): 110-117. (In Chinese)

[4] $\mathrm{Mu}$ Guangzong. Difficulties and countermeasures of institutional pension development in China [J]. Journal of Huazhong normal University (Humanities and Social Sciences Edition),2012,51(2):31-38. (In Chinese)

[5] Xu Aihua. Institutional pension service from the perspective of social work [J]. Jianghuai Forum 2010,(1): 128-133. (In Chinese)

[6] Yan Yueping, Liao Aidi. Study on the characteristics of population aging and the construction of pension service system in Yunnan [J].Journal of Chongqing University of Science and Technology(Social Sciences Edition),2015,(7):20-22. (In Chinese) 